\title{
Estimation of woody species richness and diversity using Landsat 8 OLI Satellite images
}

\author{
Estimación de la riqueza y diversidad de especies leñosas \\ mediante imágenes del satélite Landsat 8 OLI
}

\author{
Shayeste Salimi a, Javad Eshaghi Rad a*, Mahdi Erfanian b, Ahmad Alijanpour a \\ *Corresponding author: ${ }^{a}$ Urmia University, Faculty of Natural Resources, Department of Forestry, Urmia, Iran, \\ j.eshagh@urmia.ac.ir \\ ${ }^{\mathrm{b}}$ Urmia University, Faculty of Natural Resources, Department of Range and Watershed Management, Urmia, Iran.
}

\begin{abstract}
SUMMARY
One of the most important issues in forest management is preservation and development of biodiversity. This study aims at estimating richness, evenness and species diversity of woody plants in Arasbaran Protected Area (East Azerbaijan Province, Iran) using Landsat 8 OLI satellite images based on Multiple Linear Regression (MLR) and Classification and Regression Trees (CART) models. This study was performed in an elevation range of $1,000-1,850 \mathrm{~m}$. A total of 130 samples were selected based on physiographic factors. In each sampling plot, number and type of dominant tree species in the canopy were recorded. Statistical modeling was carried out by calibrating MLR and CART models. The R-squared values of MLR models were in the range of 0.10 - 0.24 for predicting richness, evenness and Shannon and Simpson's species diversity indices based on greenness as the only predictor variable (other variables were excluded from MLR models). The R-squared values of CART models were equal to $0.21,0.42,0.41$ and 0.42 , respectively. Validation of the results indicated that the CART model had a relatively better performance compared to MLR model. Overall, both methods could not estimate species richness and diversity very precisely based on Landsat 8 OLI Satellite data in the region suggesting the necessity to use high-resolution satellite data for the best evaluation of forests diversity indices in mountainous forests.
\end{abstract}

Key words: Arasbaran, Biodiversity, Image processing, Remote sensing, Iran.

\section{RESUMEN}

Una de las preocupaciones más importantes en la gestión forestal es la preservación y el desarrollo de la biodiversidad. Este estudio pretende estimar la riqueza, la uniformidad y la diversidad de especies de plantas leñosas en el Área Protegida de Arasbaran (provincia de Azerbaiyán Oriental, Irán) a partir de imágenes del satélite Landsat 8 OLI y usando modelos de Regresión Lineal Múltiple (MLR) y Árboles de Regresión y Clasificación (CART). En un rango de elevación de $1.000-1.850$ m, se seleccionaron un total de 130 muestras basadas en factores fisiográficos. En cada parcela de muestreo se registró el número y tipo de especies arbóreas dominantes en el dosel. La modelización estadística se llevó a cabo mediante la calibración de los modelos MLR y CART. Los valores de R-cuadrado de los modelos MLR estaban en el rango de 0,10 - 0,24 para predecir la riqueza, la uniformidad y los índices de diversidad de especies de Shannon y Simpson basados en el verdor como única variable predictora (otras variables fueron excluidas de los modelos MLR). Los valores de R-cuadrado de los modelos CART fueron iguales a 0,21, 0,42, 0,41 y 0,42, respectivamente. La validación de los resultados indicó que el modelo CART tenía un mejor rendimiento relativamente en comparación con el modelo MLR. En general, ningún método pudo estimar la riqueza y diversidad de especies con mucha precisión basándose en los datos del satélite Landsat 8 OLI en la región, lo que sugiere la necesidad de utilizar datos de satélite de alta resolución para la mejor evaluación de los índices de diversidad en los bosques de montaña.

Palabras clave: Arasbaran, Biodiversidad, Procesamiento de imágenes, Teledetección, Irán.

\section{INTRODUCTION}

In recent decades, the decrease in species diversity has become one of key ecological problems (Iordan et al. 2018). Species diversity plays an important role in the stability of forest ecosystems, because the presence of more species in an area will support a more complex structure of natural ecosystems, which is known to be more sustainable to changes in environmental conditions (Garet et al. 2012). The most important component of species diversity is species richness. The other component is evenness, which is related to individual's frequency distribution among species. The combination of the two concepts of richness and evenness indicate the species diversity (Morris 
et al. 2014). Recording plant species richness and diversity on the landscape scale often requires considerable time and effort (Warren et al. 2014). Remote sensing images introduce a considerable potential to supervise and predict biodiversity on many spatial and temporal scales and to provide valuable information on biodiversity distribution. Compared to other data collection methods, remote sensing techniques provide specific capabilities due to their characteristics, such as integration, repetition and a perfect spatial cover for large areas (Rocchini et al. 2016). Data obtained by remote sensing images with adequate spectral resolution could determine richness and diversity of plant species, although identification of appropriate spectral bands and their combinations is challenging (Peng et al. 2018). Applications of remote sensing in biodiversity research mainly focus on establishing the nature of the relationships between spectral information of satellite images and tree species diversity measured in the field (Madonsela et al. 2018). The use of satellite data, such as Landsat imagery, provides the advantage of using frequent multi-spectrum observations presenting acceptable and satisfactory skills for spatial estimation of biodiversity (Dube et al. 2019). Considering large archive and radiometric consistency, Landsat images can be used to analyze changes in biodiversity over long periods (Savage et al. 2015). The potential advantages of Landsat imagery for estimating tree species provide a promising tool for biodiversity monitoring (Machado et al. 2019). Several studies have used remote sensing data to estimate richness, evenness and species diversity. For example, Mohammadi and Shataee (2010) studied the relationships between species diversity index and spectrum values of Landsat ETM+ for the Hyrcanian forests (Iran). Likewise, Sivanpillai et al. (2006) analyzed the relationship between ETM+ reflective values and quantitative characteristics of loblolly pine ( $P i$ nus taeda) in East Texas in the United States. Tessler et al. (2016) studied the effects of the repeated fires on species diversity using Landsat 7 images in the Mediterranean forests and showed a huge change in vegetation diversity. In addition, Warren et al. (2014) investigated the relationship between image spectral value and plant species richness and diversity using IKONOS satellite images. The results illustrated that despite high spatial resolution of IKONOS satellite images, diversity was only estimated at a medium level that mainly depended on its low spectral resolution. Different statistical algorithms were applied to evaluate relationships between diversity indices as dependent and spectral data extracted from satellite images as independent variables in different studies.

Classification And Regression Trees (CART) and Multivariate Linear Regression models (MLR) algorithms have been widely used to evaluate these relationships (Mohammadi and Shataee 2010). The CART algorithm is a non-parametric modeling approach that recursively partitions the data to find increasingly homogeneous subsets (Mohammadi and Shataee 2010). However, CART is sensitive to small variations in training dataset, which could cause instability in variable selection and could adversely impact the predictive performance of the final model (Meng et al. 2016). The MLR method, as a parametric modeling method, has been commonly employed in forestry research. Although, this statistical technique has been criticized for its limitations, such as assumptions of both linearity and independence between variables (Dye et al. 2012). Therefore, there is a need to conduct studies to compare CART and MLR algorithms for estimating the woody species diversity using remotely sensed data.

Arasbaran deciduous forests, located in northwestern Iran, have provided high biodiversity in specific climatic conditions with an area of about 140,000 ha. These forests are very important in terms of conservation of biological reserves, prevention of soil erosion and ecotourism services. Around 1,334 plant species belonging to 493 genera and 97 families have been identified in the Arasbaran forests (Haghjou et al. 2015). To the best of our knowledge, no research has been conducted in Arasbaran forests so far, especially linking the potential of Landsat OLI imagery data to better understand biodiversity. To this aim, we here consider two working hypotheses: 1) Landsat OLI images can be used to estimate the woody species diversity, and 2) The CART method, as a non-parametric algorithm, can get more desirable results than those obtained by the MLR, as a parametric method, for estimating the woody species diversity in the Arasbaran forests. This study aims at relating NDVI (Normalized Difference Vegetation Index), NDMI (Normalized Difference Moisture Index), topographic factors (elevation, slope and aspect) and the Tasseled cap transformation components indices (obtained from Landsat 8 OLI imagery) with tree species richness, evenness and diversity in the Arasbaran forests. Finally, we also attempt to evaluate the capabilities of the CART and MLR methods as statistical modeling approaches to realize useful and applicable relationships between tree species diversity and spectral data extracted from Landsat 8 OLI images in the study area.

\section{METHODS}

Study area. This study was conducted in Arasbaran protected area with a total area of 78,560 ha, which is located at longitude of $46^{\circ} 45^{\prime} 7^{\prime}$ " to $46^{\circ} 45^{\prime}$ '52" East, and latitude of $38^{\circ} 55^{\prime} 43^{\prime \prime}$ to $38^{\circ} 56^{\prime} 22^{\prime \prime}$ North (Figure. 1). The altitude range varies from 1,000 to $1,850 \mathrm{~m}$ above sea level. The annual precipitation is about $500-600 \mathrm{~mm}$, and soil types are mostly of brown and calcareous brown (Haghjou et al. 2015).

Field sampling. A stratified random sampling method was used to define the location of sampling plots. Stratification of sampling plots followed four main aspects (North, East, South and West), three slope classes $(0-30,30-60$ and $>$ $60 \%)$, and four elevation classes $(1,000-1,250 ; 1,250$ - 


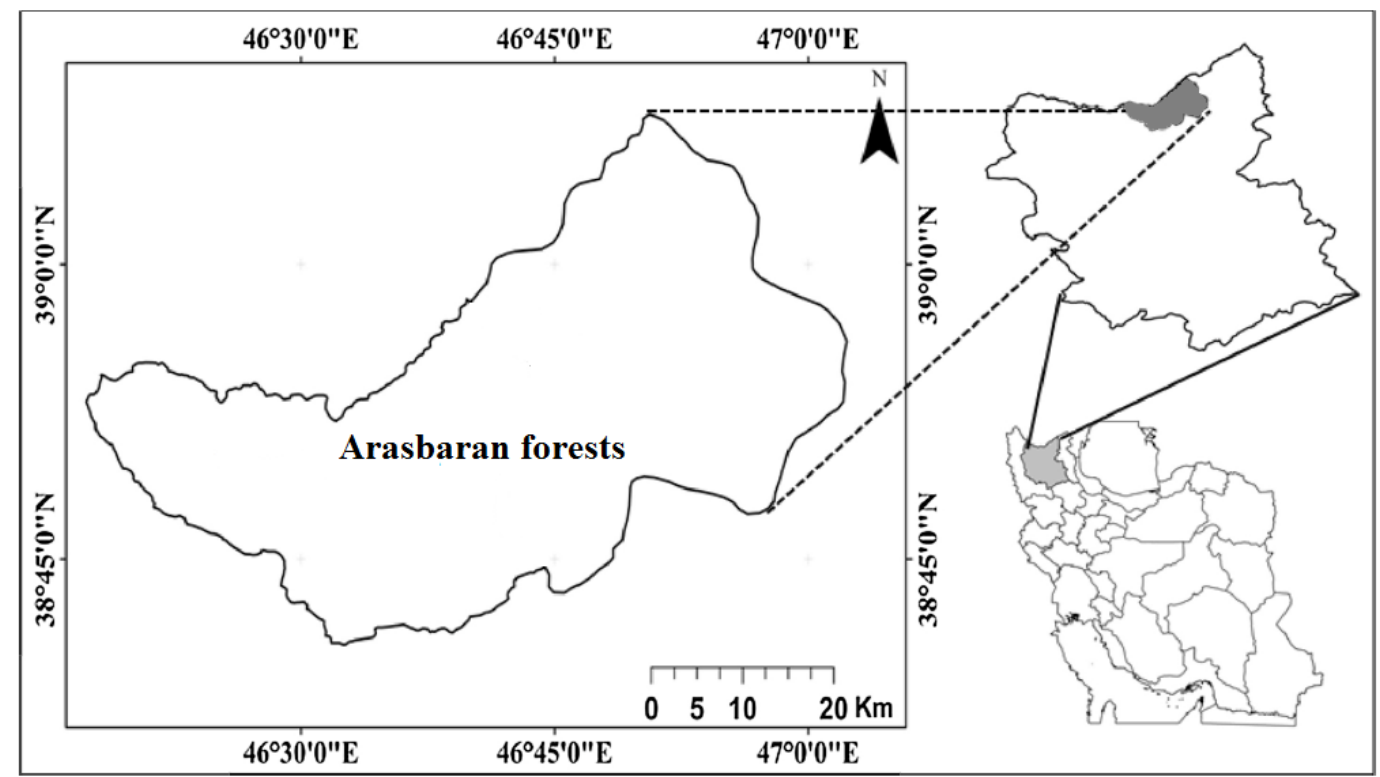

Figure 1. Location of the study area.

Ubicación de la zona de estudio.

$1,500 ; 1,500-1,750$ and $>1,750 \mathrm{~m})$. A total number of 130 samples were selected based on digital maps of elevation (m), slope (\%) and aspect (deg.) with 30-meter spatial resolution (UTM Zone 38N) that were provided in ArcGIS software for better locating plots under a proposed stratified sampling framework. The plots of $30 \mathrm{~m} \times 30 \mathrm{~m}$ were designed ensuring that corners of each plot correspond to Landsat pixels. In each sample, we recorded all tree species in the canopy layer and counted the number of individuals of each species within each sample. Thus, abundance for each species was considered as the number of individuals per sample. Geographical location of the center of each sample was obtained by GPS. Seventy percent of the collected data were randomly used at the statistical modeling stage and $30 \%$ of the remaining data were used at the validation stage.

Species diversity indices. Margalef species richness index, Shannon evenness, Shannon diversity index and Simpson diversity index were calculated based on abundance of tree species via software PC-ORD software version 5.

Landsat 8 Satellite Image Processing. The Landsat 8 image was used for the Arasbaran protected forests. Landsat 8 satellite has two main sensors: the Operational Land Imager (OLI) and the Thermal Infrared Sensor (TIRS). OLI collects images using nine spectral bands in different wavelengths of visible, near-infrared and shortwave light to observe a 185 kilometer (115 mile) wide swath of the earth in 15-30 meter resolution providing sufficient resolution to distinguish features as urban centers, farms, forests and other land uses. The red (band 4) and near-infra red (band 5) have spatial resolution of 30 meters. Radiometric and atmospheric corrections were performed using ENVI 5.3 software. The FLAASH module as a useful tool was applied for atmospheric correction (Beigiheidarlou et al. 2019). False color composite of the Landsat 8 OLI image with RGB: 543 for a representative date of growing season and cloud-free satellite image, which was available for the study area and was close to the sampling period, was used for this study. The sampling plots used to collect the tree species data in the field were overlaid on each Landsat-8 image. Raster layers of vegetation indicators including NDVI (Normalized Difference Vegetation Index) and NDMI (Normalized Difference Moisture Index), as commonly used and promising independent variables in estimation of biodiversity indices, and Tasseled Cap Transformation (TCT) components were generated corresponding to each plot using the widely used coefficients shown in Table 1 (Baig et al. 2014). In fact, the TCT compresses and decorrelates the data into few bands (i.e. brightness, greenness and wetness) associated with physical scene characteristics of the land surface. These are the most important components mostly discussed in literature (Baig et al. 2014).

Regression models: MLR and CART. The average values of spectral reflectance (0-1) obtained from kernel and the eight neighboring cells covering a specific plot, the TCT components, NDVI and NMDI, as well as slope, elevation and aspect values for each plot were extracted from the above-mentioned raster layers with a cell size of $30 \mathrm{~m}$. The TCT components were brightness, greenness and wetness. Here, the relations between above-mentioned independent 
variables and species richness, evenness and diversity indices (RiEvDi: dependent variables) were studied using MLR and CART methods in SPSS software version 21. The association between brightness, greenness, wetness, NDVI and NDMI variables and all species diversity indices was tested by correlation (Pearson correlation coefficients).

Model efficiency criteria. Regression models were validated by root mean square error (Eq. 1), bias (Eq. 2) and bias percentage (Eq. 3) (Madonsela et al. 2018) as follows:

$$
\begin{aligned}
\text { RMSE } & =\sqrt{\sum_{i=1}^{n}(X i-Y i)^{2} / n} \\
\text { Bias } & =\frac{1}{n} \sum_{i=1}^{n}(X i-Y i) \\
\text { Bias }_{r} & =\frac{\frac{1}{n} \sum_{i=1}^{n}\left(X_{i}-Y i\right)}{\bar{Y}} \times 100
\end{aligned}
$$

Let, Yi is the observed value (measured value), $\mathrm{Xi}$ is the estimated value by the regression model, and $\mathrm{n}$ is the number of observations ( 81 samples at modeling stage and 35 samples at validation stage).

\section{RESULTS}

Woody species frequency and diversity. In all, 26 woody species belonging to 13 plant families were identified in the study area (Table 2). Quercus petreae L. and Carpinus betulus $\mathrm{L}$. were the most frequent species. The mean and standard deviation of species richness, Shannon evenness, Shannon diversity and Simpson diversity indices were 3.3 $( \pm 1.01), 5.8( \pm 0.23), 0.67( \pm 0.34)$ and $0.37( \pm 0.18)$ respectively.

Predicting models. The results of the Pearson correlation analyses are given in Table 3. No significant correlation was found between all species diversity indices and brightness index, but these indices were negatively correlated with greenness, wetness, NDVI and NDMI variables.

The results of MLR model showed that greenness had a significant but lower relationship with species richness,

Table 1. Coefficients for the Tasselled Cap Transformation (TCT) for Landsat 8 bands.

Coeficientes de la Tranformación de la Capa de la Tapa (TCT) para las bandas del Landsat 8 .

\begin{tabular}{lcccccc}
\hline TCT $^{*}$ & Band 2 (Blue) & Band 3 (Green) & Band 4 (Red) & Band 5 (NIR) & Band 6 (SWIR1) & Band 7 (SWIR2) \\
\hline Brightness & 0.3029 & 0.2786 & 0.4733 & 0.5599 & 0.508 & 0.1872 \\
Greenness & -0.2941 & -0.243 & -0.5424 & 0.7276 & 0.0713 & -0.1608 \\
Wetness & 0.1511 & 0.1973 & 0.3283 & 0.3407 & -0.7117 & -0.4559 \\
\hline
\end{tabular}

* TCTs are shown here only for the first three principal components (see)

\begin{tabular}{|c|c|c|c|c|c|}
\hline Species & Family & Frequency $(\%)$ & Species & Family & Frequency $(\%)$ \\
\hline Quercus petraea L. & Fagaceae & 40.3 & Salix alba $\mathrm{L}$. & Salicaceae & 0.009 \\
\hline Carpinus betulus L. & Corylaceae & 47.4 & Corylus avellana $\mathrm{L}$. & Corylaceae & 0.009 \\
\hline Acer campestre L. & Aceraceae & 3.41 & Ulmus glabra $\mathrm{H}$. & Ulmaceae & 0.027 \\
\hline Fraxinus rotundifolia Mil. & Oleaceae & 2.48 & Cornus mas L. & Cornaceae & 0.170 \\
\hline Cotoneaster integrrima $\mathrm{M}$. & Rosaceae & 0.31 & Palliurus spina Mil. & Rhamnaceae & 0.560 \\
\hline Lonicera bractedlaris B. & Caprifoliaceae & 0.53 & Juniperus communis L. & Cupressaceae & 0.080 \\
\hline Juniperus oblonga M.B. & Cupressaceae & 0.86 & Carpinus orientalis $\mathrm{M}$. & Corylaceae & 1.115 \\
\hline Rhamnus cathartica L. & Rhamnaceae & 0.07 & Prunus cerasif Ehrh. & Rosaceae & 0.090 \\
\hline Quercus velutina Lam. & Fagaceae & 0.73 & Pyrus salicifolia Pall. & Rosaceae & 0.017 \\
\hline Sorbus torminalis L. & Rosaceae & 0.09 & Berberis Vulgaris L. & Berberidaceae & 0.009 \\
\hline Prunus avium L. & Rosaceae & 0.215 & Acer monspessulanum L. & Aceraceae & 0.090 \\
\hline Mespilus germanica L. & Rosaceae & 0.035 & cornus australis C.A.M. & Cornaceae & 0.062 \\
\hline Juglans regia $\mathrm{L}$. & Juglandaceae & 0.140 & Crataegus orientalis Pall. & Rosaceae & 1.080 \\
\hline
\end{tabular}

Table 2. The frequency of woody plant species in sampling plots in the Arasbarn area.

La frecuencia de las especies de plantas leñosas en las parcelas de muestreo en la zona de Arasbarn. 
evenness and Shannon and Simpson species diversity indices compared to brightness, wetness, NDVI and NDMI (Table 4).
The descriptive statistical parameters of independent variables of CART model are presented in Tables 5 and 6 at modeling and validation stages, respectively.

Table 3. Pearson correlation coefficients between species diversity indices and independent variables.

Coeficientes de correlación de Pearson entre los índices de diversidad de especies y las variables independientes.

\begin{tabular}{lccccc}
\hline Variables & NDMI & NDVI & Greenness & Brightness & Wetness \\
\hline Richness & -0.265 & $\mathbf{- 0 . 2 8 2}$ & $\mathbf{- 0 . 3 2 9}$ & -0.113 & $\mathbf{- 0 . 2 4 8}$ \\
Evenness & $\mathbf{- 0 . 3 9 4}$ & $\mathbf{- 0 . 3 7 5}$ & $\mathbf{- 0 . 4 1 4}$ & 0.08 & $\mathbf{- 0 . 3 8 7}$ \\
Shannon diversity & $\mathbf{- 0 . 4 6 2}$ & $\mathbf{- 0 . 4 6 1}$ & $\mathbf{- 0 . 4 8 9}$ & -0.074 & $\mathbf{- 0 . 4 4 9}$ \\
Simpson diversity & $\mathbf{- 0 . 4 4 2}$ & $\mathbf{- 0 . 4 3 9}$ & $\mathbf{- 0 . 4 7 2}$ & 0.081 & $\mathbf{- 0 . 4 3}$ \\
\hline
\end{tabular}

*Bold numbers indicate significant correlation coefficient at $5 \%$ level.

Table 4. The best linear regression models for estimating species diversity indices. For all MLR models, NDVI, NDMI, Brightness and Wetness indices were excluded from each mode by Stepwise method.

Los mejores modelos de regresión lineal para estimar los índices de diversidad de especies. Para todos los modelos MLR, los índices NDVI, NDMI, Luminosidad y Humedad fueron excluidos de cada modo por el método Stepwise.

\begin{tabular}{lccccccccc}
\hline Predictant & Predictor & Coefficient & Intercept & $\mathrm{R}^{2}$ & Adjunted $R^{2}$ & RMSE & Bias & F & Sig. \\
\hline Richness & Greenness & 5.171 & -8.022 & 0.10 & 0.104 & 0.93 & 0.057 & 14.636 & $\mathbf{0 . 0 0 0}^{* *}$ \\
Evenness & Greenness & 1.135 & -2.340 & 0.17 & 0.207 & 0.37 & -0.020 & 31.456 & $\mathbf{0 . 0 0 0}^{* *}$ \\
Shannon diversity & Greenness & 1.574 & -3.825 & 0.24 & 0.252 & 0.46 & -0.020 & 40.371 & $\mathbf{0 . 0 0 0}^{* *}$ \\
Simpson diversity & Greenness & 0.882 & -2.131 & 0.22 & 0.252 & 0.50 & -0.007 & 40.330 & $\mathbf{0 . 0 0 0}^{* *}$ \\
\hline
\end{tabular}

Table 5. Descriptive statistics of independent variables at CART modeling step.

Estadísticas descriptivas de las variables independientes en el paso de modelización CART.

\begin{tabular}{lcccccccc}
\hline \multicolumn{1}{c}{ Parameters } & Elevation $(\mathrm{m})$ & Aspect (deg.) & Slope $(\%)$ & NDMI & NDVI & Wetness & Greenness & Brightness \\
\hline Minimum & 1,140 & 1.80 & 2.12 & 0.10 & 0.52 & -0.10 & 0.10 & 0.270 \\
Maximum & 2,155 & 359.58 & 56.74 & 0.45 & 0.89 & 0.02 & 0.32 & 0.460 \\
Mean & $1,505.2$ & 184.65 & 43.47 & 0.32 & 0.80 & -0.01 & 0.23 & 0.370 \\
Std. Dev. & 80.266 & 117.49 & 19.68 & 0.08 & 0.09 & 0.027 & 0.049 & 0.036 \\
Sample size & 81 & 81 & 81 & 81 & 81 & 81 & 81 & 81 \\
\hline
\end{tabular}

Table 6. Descriptive statistics of independent variables at CART validation step.

Estadísticas descriptivas de las variables independientes en la etapa de validación de CART.

\begin{tabular}{lcccccccc}
\hline Parameters & Elevation $(\mathrm{m})$ & Aspect (deg.) & Slop $(\%)$ & NDMI & NDVI & Wetness & Greenness & Brightness \\
\hline Minimum & 1,319 & 6.0090 & 15.920 & 0.15 & 0.630 & -0.080 & 0.130 & 0.280 \\
Maximum & 1,829 & 356.98 & 100.14 & 0.44 & 0.900 & 0.020 & 0.290 & 0.460 \\
Mean & $1,526.89$ & 190.93 & 47.41 & 0.318 & 0.800 & -0.020 & 0.230 & 0.370 \\
Std. Dev. & 166.76 & 114.67 & 17.540 & 0.080 & 0.075 & 0.026 & 0.044 & 0.038 \\
Sample size & 35 & 35 & 35 & 35 & 35 & 35 & 35 & 35 \\
\hline
\end{tabular}


As shown in Figure 2, the most suitable CART model to estimate species richness had 6 nodes. Greenness and brightness variables were considered as the most important estimator to form decision tree branches.

CART model had 20 nodes to estimate species evenness. Wetness and greenness variables were selected as effective variables in creating the branches (Figure 3). In general, using the last nodes approach, separator variables (decision) are less important than variables of the first node (higher levels of the decision tree).

CART model had 34 nodes for estimating Shannon species diversity, in which two vegetation indices (greenness and NDVI) were defined as the most important decision variable for creating the first and second nodes (Figure 4).

In the first and second nodes of the CART model used to estimate Simpson species diversity, vegetation was an effective variable on estimation of Simpson's diversity index of woody species (Figure 5).

The values of RMSE, RMSEr, Bias and Bias \% for modeling stage are given in Table 7 and those for validation stage are presented in Table 8.

The results of CART model showed that greenness and wetness were respectively selected for estimating species

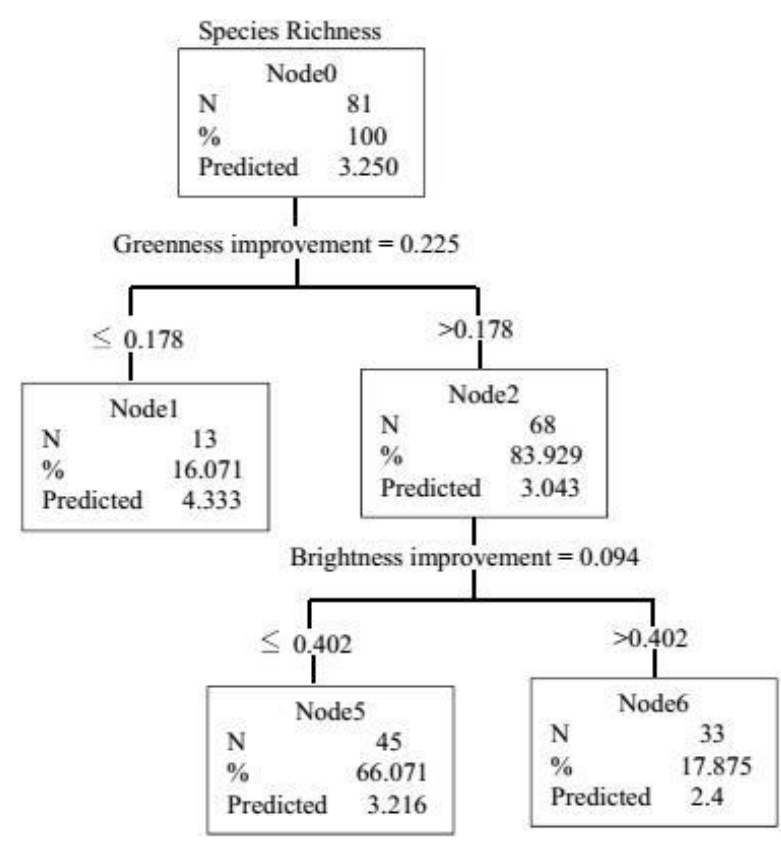

Figure 2. CART decision tree to estimate species richness.

Árbol de decisión CART para estimar la riqueza de especies.

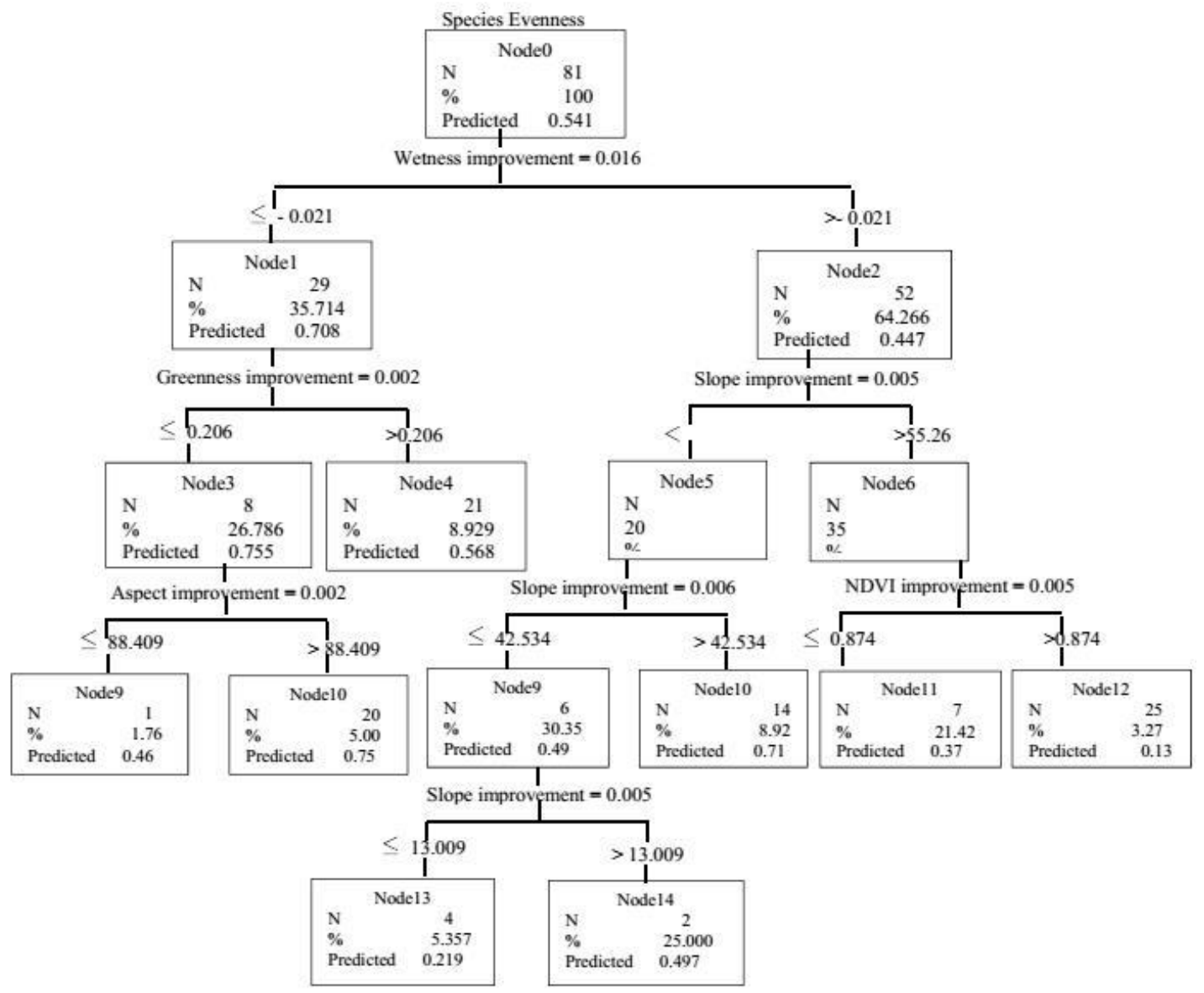

Figure 3. CART decision tree to estimate species evenness.

Árbol de decisión CART para estimar la uniformidad de las especies. 


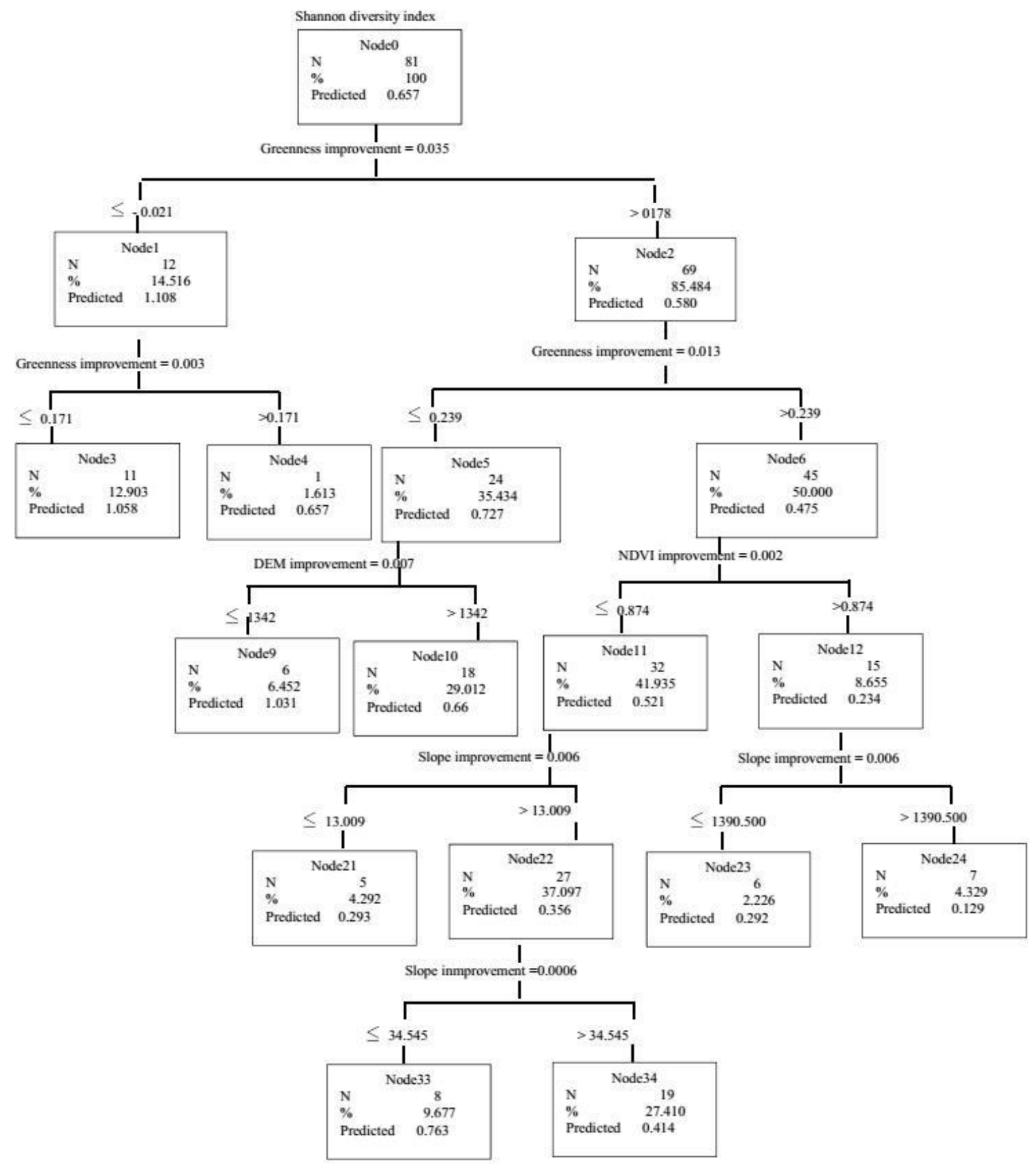

Figure 4. CART decision tree to estimate Shannon species diversity.

Árbol de decisión CART para estimar la diversidad de especies - índice de Shannon.

Table 7. CART performance criteria at modeling step. Criterios de rendimiento de CART en la etapa de modelización.

\begin{tabular}{lcccc}
\hline Species Indices & Bias\% & Bias & RMSE & $\mathbf{R}^{2}$ \\
\hline Richness & 0.03 & 0.08 & 1.85 & 0.21 \\
Evenness & 0.04 & 0.01 & 0.17 & 0.42 \\
Shannon diversity & 0.01 & 0.007 & 0.27 & 0.41 \\
Simpson diversity & 0.09 & 0.03 & 0.15 & 0.42 \\
\hline
\end{tabular}

Table 8. CART performance criteria at validation step.

Criterios de rendimiento de CART en la etapa de validación.

\begin{tabular}{lcccc}
\hline Species Indices & Bias\% & Bias & RMSE & $\mathbf{R}^{2}$ \\
\hline Richness & 3.2 & 0.10 & 1.33 & 0.04 \\
Evenness & 4.3 & 0.02 & 0.24 & 0.15 \\
Shannon diversity & 8.1 & 0.05 & 0.37 & 0.22 \\
Simpson diversity & 7.9 & 0.03 & 0.18 & 0.04 \\
\hline
\end{tabular}




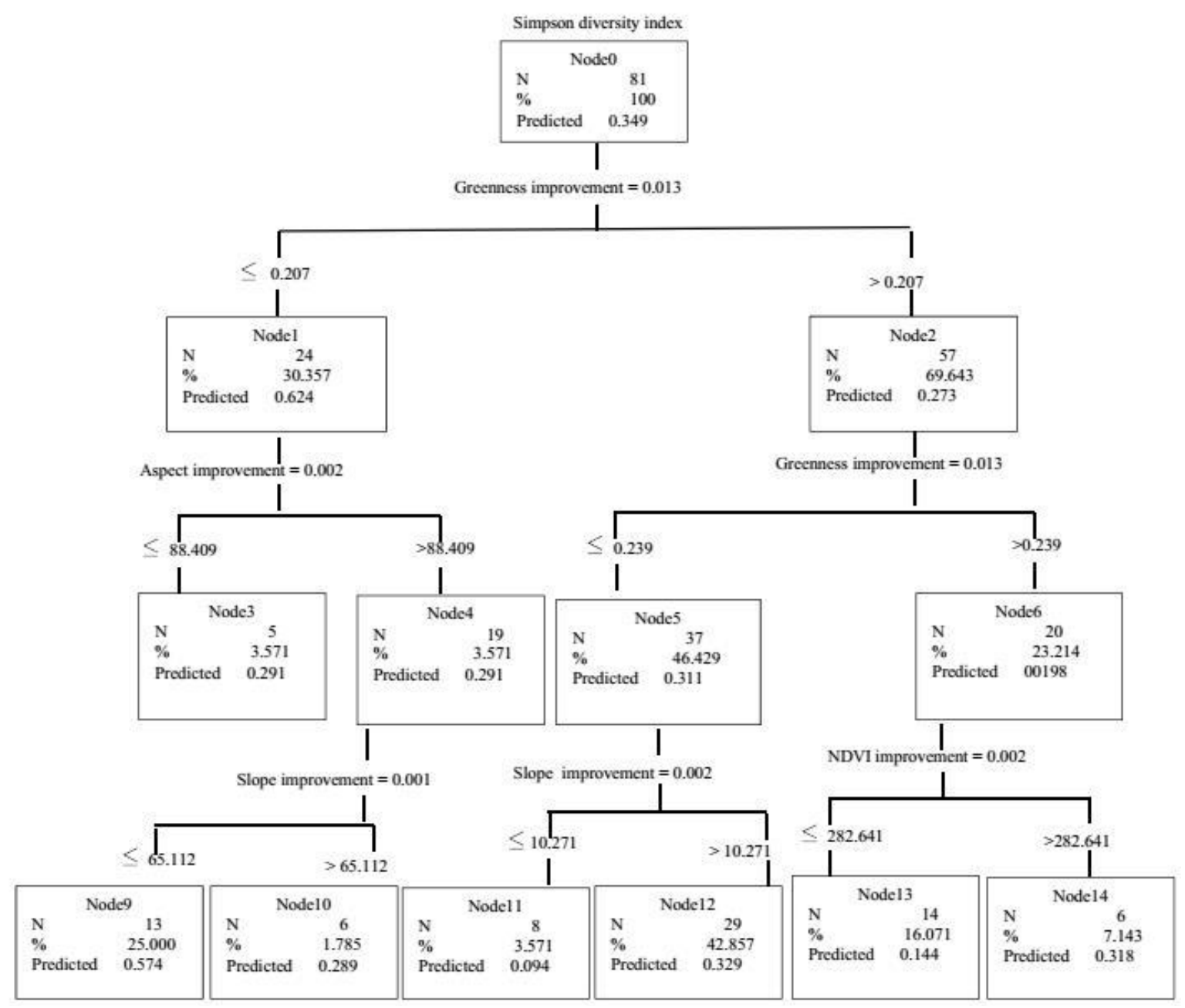

Figure 5. CART decision tree to estimate Simpson species diversity.

Árbol de decisión CART para estimar la diversidad de especies - índice de Shannon.

richness, Shannon and Simpson diversity indices and wetness for evenness index, which were the best predictors compared to other variables in the modeling step (Table 7). Although regarding the results of CART models error criterion at validation stage, this model was more effective in estimating the species evenness, Shannon diversity indices compared to other indices (Table 8). Figures 6 - 9 show distribution plot diagrams using graphical comparison of the results of CART model with the measured values of plant diversity indicators (center of samples) at validation stage. The closer to distribution points to the ideal fit line 1: 1 , the more accurate they will represent modeling. The point below the line means underestimation and the point over the line means overestimation

\section{DISCUSSION}

This study was conducted to investigate the relationship between the field-based estimations of woody species richness and diversity indices and spectral data extracted from satellite images. All species diversity indices were negatively correlated with greenness, wetness, NDVI and NDMI variables in the Arasbaran forests (Table 2). This seems to be mainly due to the fact that many plots were dominated by oak (Quercus petraea) and hornbeam (Carpinus betulus) in the study area. The stands where the number of tree species was low and stem density was high in the region had lower diversity, although produced higher spectral values (Ozdemir and Karnieli 2011). In this regard, similar result were reported by Madonsela et al. (2018) who stated that Shannon diversity index was negatively correlated with NDVI when influenced by monospecies canopy cover. Similarly, NDVI had the lowest correlation with species richness in dry forests in Brazil (Medeiros et al. 2019), wetlands in Italy (Rocchini et al. 2016) and in dry tropical forests in India (Nagendra et al. 2010). These results might be statistically significant because vegetation indices such as the NDVI decrease amplitude of values by rescaling the original data influencing pixel value dispersion (Rocchini et al. 2016). In addition, Peng 


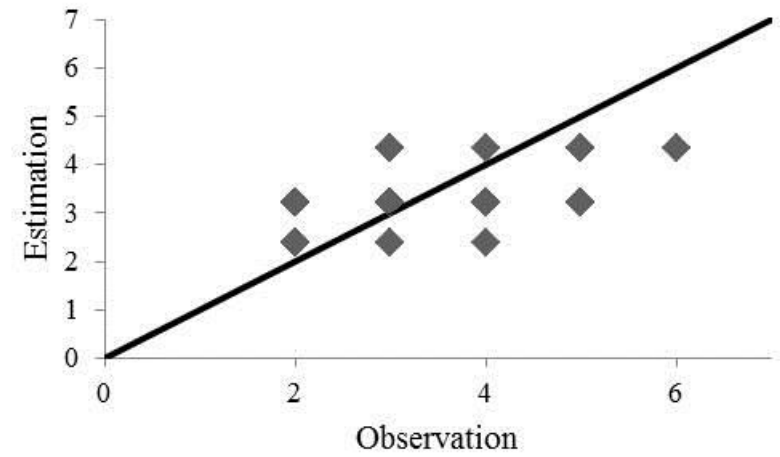

Figure 6. Scatter plot species richness of Arasbaran protected area. de Arasbaran.

Gráfico de dispersión de riqueza de especies del área protegida

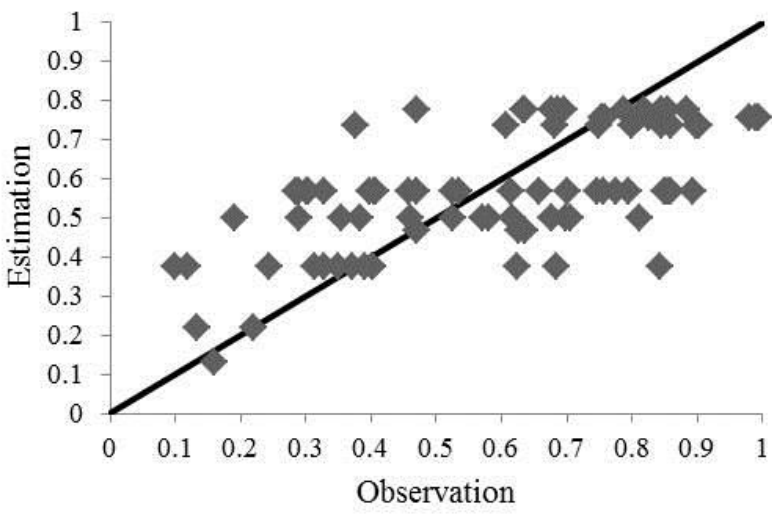

Figure 7. Scatter plot of species evenness of Arasbaran protected area.

Gráfico de dispersión de uniformidad de especies del área protegida de Arasbaran.

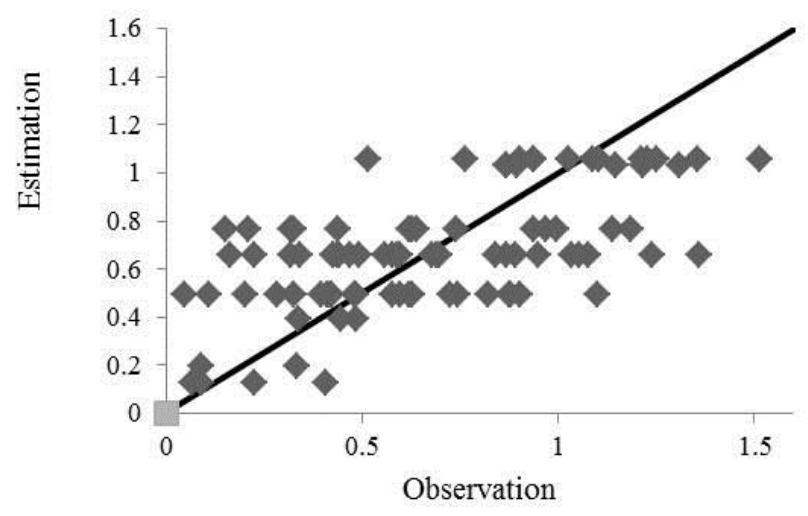

Figure 8. Scatter plot of Shanon diversity of Arasbaran protected area.

Gráfico de dispersión de diversidad - índice de Shanon - en el área protegida de Arasbaran.

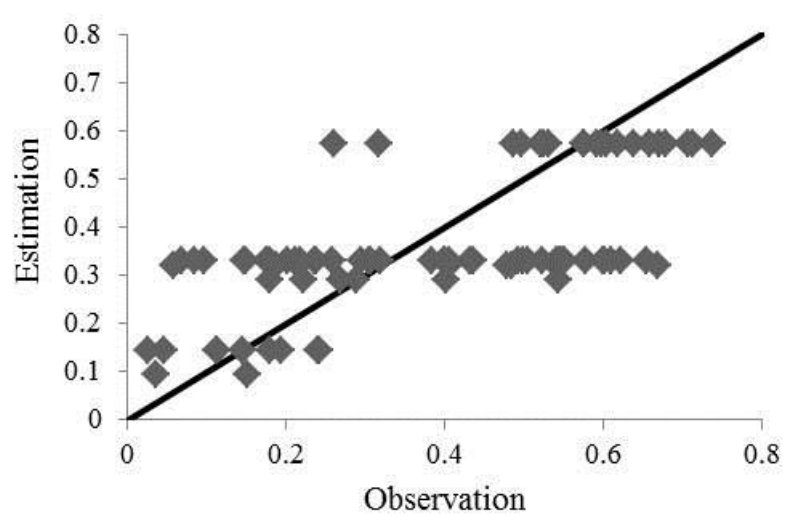

Figure 9. Scatter plot of Simpson diversity of Arasbaran protected area.

Gráfico de dispersión de la diversidad de Simpson en el área protegida de Arasbaran.

et al. (2018) found that plant diversity indices were not significantly related to reflectance and Meng et al. (2016) obtained very low and non-statistically significant correlations when the stand was dominated by the coniferous tree species, such as Cunninghamia lanceolata and Pinus massoniana. Although these correlations were reported to be significantly positive in temperate forests in Iran (Mohammadi and Shataee 2010). In contrast, Chitale et al. (2019) observed very high correlation between remote sensing-based vegetation indices and plant richness in dry deciduous forests. The acquired mixed reflectance of various plant species is effected by water content, leaf thickness, mesophyll structure and canopy structure (Sytar et al. 2017). Overall, the type of forest and complexity of forest stands in points of multi-layers and species composition can affect on the output of estimations. Also, low spatial resolution imagery or large pixel size of Landsat 8 OLI may lead to estimate low-precision results, especially for the extraction of tree diversity indices, due to its finer detection weakness of spectral reflections of forest canopy.

The results of MLR model showed that greenness had a significant relationship with all diversity indices. However, brightness, wetness, NDVI and NDMI had no significant explanatory power for estimating tree species diversity via MLR models (Table 4). Consistent with this assertion, Madonsela et al. (2018) indicated that interaction between NDVI and woody canopy cover was not significant in explaining tree species diversity. Moreover, Mohammadi and Shataee (2010) revealed that NDVI, brightness and greenness were the most important variable determining species richness and Simpson index variability in the temperate forests of Iran. Although, our obtained $R^{2}$ values of MLR were lower than those of other studies for estimation of different plant diversity indices. Mohammadi and Shataee (2010) reported a value of $R^{2}=0.59$ for species richness and $R^{2}=0.45$ for Simpson diversity using 
Landsat ETM+ in Hyrcanian forests of Iran. In addition, Medeiros et al. (2019) illustrated a significant positive correlation between the near-infrared spectral band (Landsat $8 \mathrm{OLI})$ and the woody species richness $\left(R^{2}=0.74, P<\right.$ $0.001)$ in the largest dry forests in South America and this band could be used for estimation of the species richness using power and quadratic regression models.

Based on CART models, greenness and wetness were defined as model predictors to estimate species richness and diversity indices in the Arasbaran forests. Generally, this model was more effective in estimating woody species evenness and Shannon diversity indices according to low values of RMSE and Bias values (see all scatter plots). This is mainly because species richness is more influenced than Shannon diversity index by the presence of rare species (Ricotta et al. 2008). Implementation of CART model showed more explanatory power for estimation of plant diversity using Landsat ETM+ data in the Hyrcanian forests, northern of Iran (Mohammadi and Shataee 2010) and in tropical forests (Gillespie et al. 2009). Comparison of the results of MLR and decision tree in CART models showed that the efficiency of CART model was significantly better for estimating species diversity indices than that of MLR model, which is consistent with a previous work (Mohammadi and Shataee 2010). In addition, It was stated that CART, which did not need to make any assumptions about the data, was a more robust statistical method to investigate complex relationship between diversity variables and remotely sensed data (Meng et al. 2016).

\section{CONCLUSIONS}

Overall, in this study, we evaluated the capability of Landsat 8 OLI Satellite image for the modeling and estimation of various diversity indices, such as species richness and diversity in the Arasbaran forests in Iran by two methods: MLR and CART. The results of this study showed that the efficiency of CART model was considerably higher than that of MLR for estimating woody species evenness and Shannon diversity indices. Although CART could not estimate species richness and diversity very precisely based on Landsat 8 OLI Satellite data in the region, suggesting the necessity to use high-resolution satellite data for the best evaluation of forest species richness in mountainous forests.

\section{ACKNOWLEDGMENT}

This paper has been extracted from a master thesis research which was financially supported by Urmia University, Iran. We appreciate scientific advise and suggestions given by anonymoous reviewers.

\section{REFERENCES}

Baig MHA, L Zhang, T Shuai, Q Tong. 2014. Derivation of a tasselled cap transformation based on Landsat 8 at-satellite reflectance. Remote Sensing Letters 5(5): 423-431. DOI: http://dx.doi.org/10.1080/2150704x.2014.915434

Beigiheidarlou H, A Banj Shafiei, M Erfanian, A Tayyebi, A Alijanpour. 2019. Effects of preservation policy on land use changes in Iranian Northern Zagros forests. Land Use Policy 81: 76-90. DOI: https://doi.org/10.1016/j.landusepol.2018.10.036

Chitale VS, MD Behera, PS Roy. 2019. Deciphering plant richness using satellite remote sensing: a study from three biodiversity hotspots. Biodiversity and Conservation 28(8): 2183-2196. DOI: https://doi.org/10.1007/s10531-019$\underline{01761-4}$

Dube T, S Pandit, C Shoko, A Ramoelo, D Mazvimavi, T Dalu. 2019. Numerical assessments of Leaf Area Index in tropical Savanna rangelands, South Africa using Landsat 8 OLI derived metrics and In-situ measurements. Remote Sensing 11: 829. DOI: https://doi.org/10.3390/rs11070829

Dye M, O Mutanga, R Ismail. 2012. Combining spectral and textural remote sensing variables using random forests: predicting the age of Pinus patula forests in KwaZulu-Natal, South Africa. Journal of Spatial Science 57(2): 193-211. DOI: https://doi.org/10.1080/14498596.2012.733620

Garet J, F Raulier, D Pothier, SG Cumming. 2012. Forest age class structures as indicators of sustainability in boreal forest: are we measuring them correctly? Ecological Indicators 23: 202-210. DOI: https://doi.org/10.1016/j.ecolind.2012.03.032

Gillespie T, S Saatchi, S Pau, S Bohlman, A Giorgi, S Lewis. 2009. Towards quantifying tropical tree species richness in tropical forests. International Journal of Remote Sensing 30(6): 1629-1634. DOI: https://doi. org/10.1080/01431160802524552

Haghjou M, B Hayati, E Pishbahar, M Molaei, M Haghjou. 2015. The economic valuation of Arasbaran forests' animal species in Iran (An application of contingent ranking approach). Indian Journal of Natural Sciences 31(6): 96059615 (In Persian).

Iordan CM, F Verones, F Cherubini. 2018. Integrating impacts on climate change and biodiversity from forest harvest in Norway. Ecological Indicators 89: 411-421. DOI: https:// doi.org/10.1016/j.ecolind.2018.02.034

Kalbi S, A Fallah, S Shataee. 2014. Estimation of forest attributes in the Hyrcanian forests, comparison of advanced space-borne thermal emission and reflection radiometer and satellite poure I'observation de la terre-high resolution grounding data by multiple linear, and classification and regression tree regression models. Journal of Applied Remote Sensing 8(1): 083632. DOI: https://doi.org/10.1117/1. JRS.8.083632

Machado CCC, JD Galvíncio, MSB de Moura, HFP de Araujo. 2019. Predicting plant species richness with satellite images in the largest dry forest nucleus in South America. Journal of Arid Environments 166: 43-50. DOI: https://doi. org/10.1016/j.jaridenv.2019.03.001

Madonsela S, MA Cho, A Ramoelo, O Mutanga, L Naidoo. 2018. Estimating tree species diversity in the savannah using NDVI and woody canopy cover. International Journal of Applied Earth Observation and Geoinformation 66: 106115. DOI: https://doi.org/10.1016/j.jag.2017.11.005

Medeiros E, C Machado, J Galvincio, M Moura, H Araujo. 2019. Predicting plant species richness with satellite images in the 
largest dry forest nucleus in South America. Journal of Arid Environments 166: 43-50. DOI: https://doi.org/10.1016/j. jaridenv.2019.03.001

Meng J, S Li, W Wang, Q Liu, S Xie, W Ma. 2016. Estimation of forest structural diversity using the spectral and textural information derived from SPOT-5 satellite images. Remote Sensing 8(2): 125. DOI: https://doi.org/10.3390/rs8020125

Mohammadi J, S Shataee. 2010. Possibility investigation of tree diversity mapping using Landsat ETM+ data in the Hyrcanian forests of Iran. Remote Sensing of Environment 114(7): 1504-1512. DOI: https://doi.org/10.1016/j. rse.2010.02.004

Morris EK, T Caruso, F Buscot, M Fischer, C Hancock, TS Maier, T Meiners, C Müller, E Obermaier, D Prati. 2014. Choosing and using diversity indices: insights for ecological applications from the German Biodiversity Exploratories. Ecology and Evolution 4(18): 3514-3524. DOI: https://doi.org/10.1002/ece3.1155

Nagendra H, D Rocchini, R Ghate, B Sharma, S Pareeth. 2010. Assessing plant diversity in a dry tropical forest: comparing the utility of Landsat and IKONOS satellite images. Remote sensing 2: 478-496. DOI: https://doi.org/10.3390/rs2020478

Ozdemir I, A Karnieli. 2011. Predicting forest structural parameters using the image texture derived from worldview-2 multispectral imagery in a dryland forest, israel. International journal applied earth observation geoinformation, 13: 701-710.

Peng Y, M Fan, J Song, T Cui, R Li. 2018. Assessment of plant species diversity based on hyperspectral indices at a fine scale. Scientific Report, 8(1): 4776. DOI: https://doi. org/10.1038/s41598-018-23136-5

Ricotta C, S Godefroid, L Celesti-Grapow. 2008. Common species have lower taxonomic diversity Evidence from the urban floras of Brussels and Rome. Diversity and Distributions 14(3): 530-537. DOI: https://doi.org/10.1111/j.14724642.2008.00467.x

Rocchini D, DS Boyd, JB Féret, GM Foody, KS He, A Lausch, H Nagendra, M Wegmann, N Pettorelli. 2016. Satellite remote sensing to monitor species diversity: Potential and pitfalls. Remote Sensing in Ecology and Conservation 2(1): 25-36. DOI: https://doi.org/10.1002/rse2.9

Savage SL, RL Lawrence, JR Squires. 2015. Predicting relative species composition within mixed conifer forest pixels using zero-inflated models and Landsat imagery. Remote Sensing of Environment, 171: 326-336. DOI: https://doi. org/10.1016/j.rse.2015.10.013

Sivanpillai R, CT Smith, R Srinivasan, MG Messina, XB Wu. 2006. Estimation of managed loblolly pine stand age and density with Landsat ETM+ data. Forest Ecology and Management 223(1-3): 247-254. DOI: https://doi.org/10.1016/j. $\underline{\text { foreco.2005.11.013 }}$

Sytar O, M Brestic, M Zivcak, K Olsovska, M Kovar, H Shao, X He. 2017. Applying hyperspectral imaging to explore natural plant diversity towards improving salt stress tolerance. Science of the Total Environment 578: 90-99. DOI: https:// doi.org/10.1016/j.scitotenv.2016.08.014

Tessler N, L Wittenberg, N Greenbaum. 2016. Vegetation cover and species richness after recurrent forest fires in the Eastern Mediterranean ecosystem of Mount Carmel, Israel. Science of the Total Environment 572: 1395-1402. DOI: https://doi.org/10.1016/j.scitotenv.2016.02.113

Warren SD, M Alt, KD Olson, SD Irl, MJ Steinbauer, A Jentsch. 2014. The relationship between the spectral diversity of satellite imagery, habitat heterogeneity, and plant species richness. Ecological Informatics 24: 160-168. DOI: https:// doi.org/10.1016/j.ecoinf.2014.08.006

Recibido: $25 / 12 / 20$

Aceptado: 05/11/21 
